\title{
RESEARCH INTO THE EFFECTS OF THE EFFECTIVE MICROORGANISMS ADDITION ON THE ENGINE OIL VISCOSITY
}

\author{
Rafał Krakowski \\ Faculty of Marine Engineering \\ Morska Street 83, 81-225 Gdynia, Poland \\ tel.: +48586901398 \\ e-mail:r.krakowski@wm.umg.edu.pl
}

\begin{abstract}
In the article, changes in the properties of oils during operation were characterized. The main reason for this is the continuous aging process of the used oil caused by the interaction of oxygen contained in the air, which reacts relatively easily with hydrocarbons and the oxidation process is accelerated just by high temperature. Then the problem of microorganisms occurring in petroleum products and their effect on the properties of oils and the operation of the internal combustion engine was presented. The next part of the article presents effective microorganisms, i.e. what they are and how they work, in particular, their composition and appropriate development conditions. In addition, some of their specific applications were briefly described. In the next part of the article, the research methodology, applied oil samples with additives of effective microorganisms, both for fresh oil and used oil were described. In addition, the measuring test stand with instrumentation and measuring device was shown. The main part of the article contains the characteristics of dynamic viscosity as a function of temperature for fresh oil and used oil compared with oils with the addition of microorganisms in liquid form and ceramic tubes. The developed graphs enabled analysis of the effect of the addition of microorganisms on oil viscosity as ecological products.
\end{abstract}

Keywords: petroleum products, oil viscosity, engine oil, microbiological contamination, effective microorganisms

\section{Introduction}

In petroleum products, a serious problem is microbiological contamination, which includes car fuels, aircraft fuels, as well as marine fuels, transformer and engine oils as well as lubricants and oil emulsions. With the development of industry and broadly understood motorization, including also aviation and ships, it turned out that the problem of microbial contamination is still valid and is becoming more and more common $[1,6]$.

Dynamic development of the automotive industry, as well as aviation and shipbuilding industry and related progressive increase in demand for hydrocarbon fuels resulted in increased interest in microorganism development phenomena in fuels and oils as well as in fuel and lubricating oil installations $[3,6]$.

Many species of bacteria and fungi have the ability to grow in petroleum products that are a source of carbon and energy. Therefore, the life activity of microorganisms causes the decomposition of hydrocarbons and refining additives and the release of water, sulphur compounds, surface-active substances to the fuel. The result is changes in the chemical composition of the fuel and the value of some physical parameters, such as boiling point, acid number or viscosity. Currently, there are many methods of controlling or limiting microorganisms in petroleum products, such as physical methods, thermal decontamination and chemical methods, while the present study analyses the impact of the addition of effective microorganisms on fresh oil and oil used on viscosity as one of the parameters characterizing oil [7].

\section{Changes in oil properties during operation}

The continuous aging process of the used oil is caused inter alia by the interaction of oxygen 
contained in the air, which reacts relatively easily with hydrocarbons. As a result of their oxidation, compounds with the structure of alcohols, aldehydes and organic acids are formed. Then, the resin products undergo secondary condensation reactions in the form of hard-to-remove lakes, deposited on the internal surfaces of the engine. At the same time, there is the simultaneous detachment of the hydrogen atoms from hydrocarbon chains, which leads to creation of double bonds, which is the cause of parallel polymerization processes. After very long runs, the oil turns into a thick, black tar, unable to lubricate anything, and in extreme cases - even into a solid. The oxidation process is accelerated by high temperature, because it causes thermal decomposition of base oil hydrocarbons, viscosity modifiers and some refining additives [11, 12]. The scheme of the deterioration of engine oil quality during operation is shown in Fig. 1.

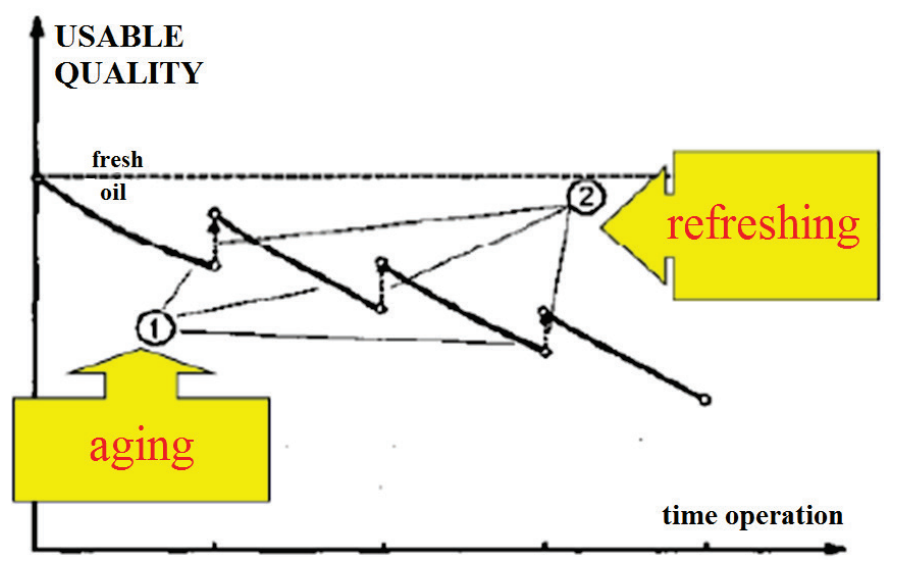

Fig. 1. Deterioration scheme of engine oil quality during operation [5]

The operating conditions of engine oil determine its quantitative and qualitative consumption (in particular, the operating temperature affects the intensity of physicochemical transformations, e.g. oxidation). The quality, composition and physicochemical properties of engine oil are important engine operating factors that can greatly affect the composition and level of emissions of toxic components formed in the engine's working process.

The influence of engine oil on the emission of toxic exhaust components also takes place by acting on the efficiency of the catalytic exhaust purification systems. The parameters of engine oils during engine operation are not uniform and change depending on the operating conditions, the number of kilometres travelled, the time of operation, the technical condition of the engine and elements cooperating with it.

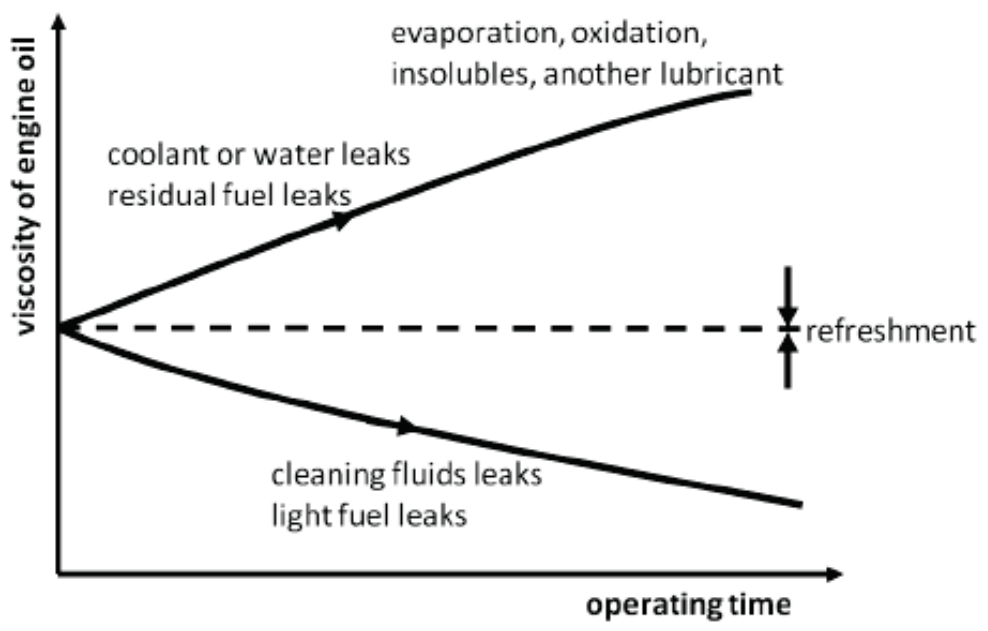

Fig. 2. Changes in viscosity of engine oil during exploitation [8] 
Any changes in the properties of lubricating oils that go beyond the lower and upper limits that are accepted for them, have negative effects in the form of the possibility of damage occurring and increase of the emission of toxic exhaust components. The viscosity of the engine oil, which is subject to complex operational influences, changes - it can increase or decrease. In Fig. 2, schematically changes in oil properties during operation have been presented.

Therefore, for engine, it is important not only to choose the type of oil correctly but also to monitor its viscosity. If a change in the oil viscosity is detected, further analysis of the oil can identify the cause of the disturbance of its properties. Variation in the oil viscosity is often the first indicator of a global problem of the tribological unit $[2,4,9]$.

\section{Microbes in petroleum products}

A good quality petroleum product must be clear and transparent, while the growth of microorganisms can often contribute to its cloudiness and darkening. Microbiological contamination is caused by a number of factors, including changes in fuel and oil sources and their quality. In addition, the increasing use of additives that can provide compounds for the growth of microorganisms, changes in the management and storage of these products, also have an impact on the development of microorganisms in the petroleum product.

The presence of microbes in the system can cause:

a) production of compounds with corrosive action, causing destruction of tanks, and thus an increase in the amount of bellows pollution,

b) adverse changes in physicochemical properties caused by the decomposition of hydrocarbons and refining additives, which results in a decrease in chemical and thermal stability,

c) manufacture of surface-active substances,

d) formation of sediments and biological membranes on the walls of tanks and pipes that contaminate the product after detaching from the ground,

e) clogging of filters and hoses during operation.

The bio-additives introduced in recent years contribute to the development of microbiological life in reservoirs. As a consequence, it can lead to serious problems with the efficient flow of petroleum products through filters (and even prevent this flow), as well as significantly accelerate the corrosion of the tank walls [3].

\section{Effective microorganisms (EM)}

Effective microorganisms are specially selected and appropriately selected smallest organisms on Earth. A composition composed of 81 different strains of aerobic and anaerobic microorganisms (Fig. 3), among others lactic bacteria (Lactobacillus casei, Streptococcus lactis), yeast (Saccharomyces, Candida utilis), photosynthetic bacteria (Rhodopseudomonas palustris, Rhodobacterspae), mould (Aspergillus oryzae, Mucom hiemalis), as well as actinomyces (Streptomyces, Streptomyces griseus). This composition was developed by Teruo Higa from the University of Agriculture at University of the Ryukyus in Okinawa, Japan. According to the author, correctly and systematically introduced into the environment, they give him the biodynamic potential of self-renewal and regeneration [7]. Photosynthetic bacteria, using available conditions, e.g. $\mathrm{CO}_{2}$ and temperature, produce biochemical compounds active from organic matter or toxic gases useful. Lactic acid bacteria also slow down the development of harmful bacteria. Another important component of the mix is yeast. Thanks to fermenting fungi, organic matter decomposes and neutralizes unpleasant odours. The principle of EM operation is based only on natural processes; they are not genetically modified and completely environmentally friendly. Both types of microorganisms, i.e. aerobic and anaerobic, play an extremely important role in binding nitrogen. Oxygen microorganisms support the development and maintenance of life, and anaerobic digestion of dangerous or used substances [10]. 


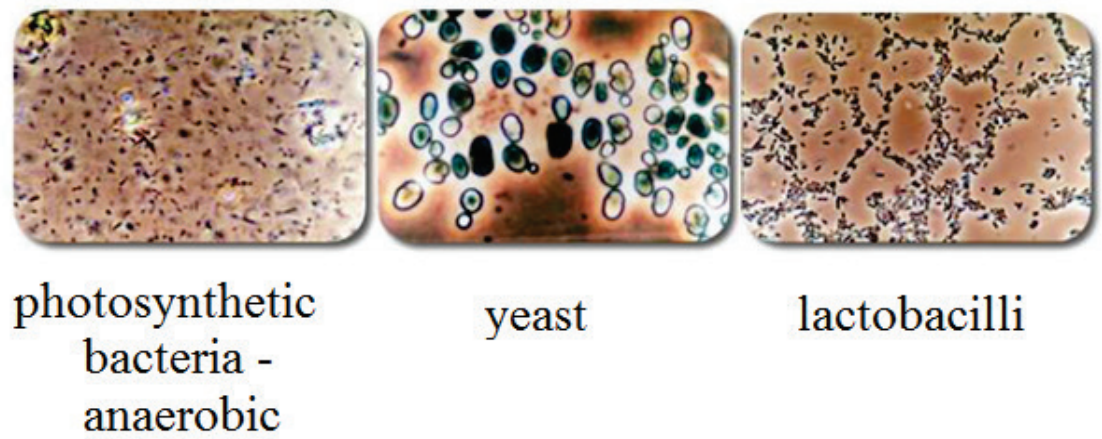

Fig. 3. A composition composed of various strains of aerobic and anaerobic microorganisms that are part of effective microorganisms [14]

\section{The research methodology}

In the conducted tests, the dynamic viscosity of engine oil was measured. For this purpose, the SV vibrating viscometer has been used (Fig. 4).

a)

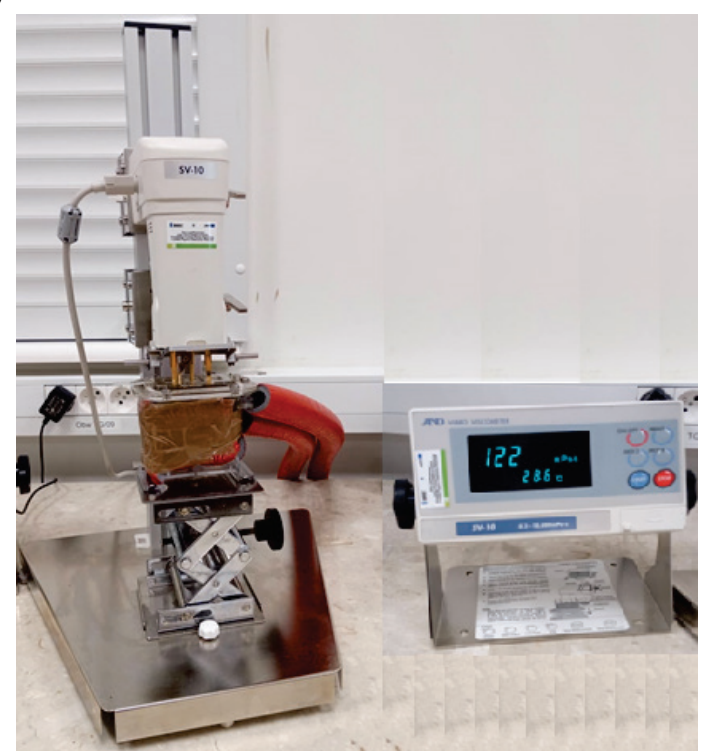

b)

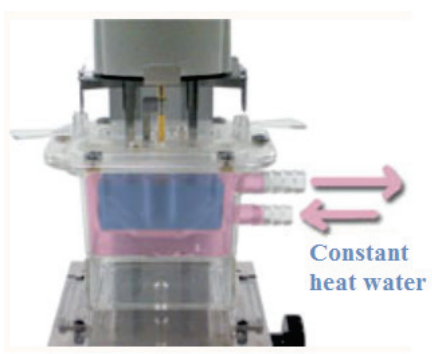

c)

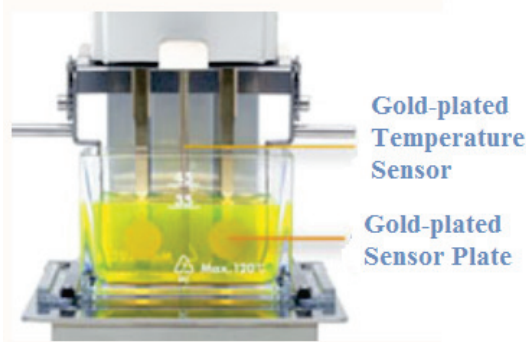

Fig. 4. Measuring stand: a) vibratory viscometer SV with vibrating fork, b) water jacket, c) sensor unit [17]

\section{Measurement Principle for SV series}

The SV series has of 2 thin sensor plates that are driven with electromagnetic force at the same frequency by vibrating at constant sine-wave vibration in reverse phase like a tuning- fork. The electromagnetic drive controls the vibration of the sensor plates to keep in constant amplitude. The driving electric current, which is exciting force, will be detected as the magnitude of viscidity produced between the sensor plates and the sample fluid.

\section{Sensor Unit}

Corrosive-resistant gold-plate sensor plate and temperature sensor. It is very important to measure the temperature of the fluid correctly because the viscosity is very much dependent upon the temperature of the fluid. SV series can detect accurate temperature immediately because the fluid and the detection unit (sensor plates) with small surface area/thermal capacity reach the thermal equilibrium in only a few seconds.

SV series, Tuning-fork Vibration Method does not cause damage to the sample fluid and allows measurement of cloud point of samples such as surface-active agents and of 
surface/interface changes such as wettability because of its excellent feature for wide measurement range without the need to replace the sensor plates.

\section{Water Jacket}

Our water jacket used in conjunction with a constant heat water tank to heat the circulating system, ensures that the sample remains at a constant temperature and that the temperature can be changed for viscosity measurement [13].

The tests were carried out using samples of the $5 \mathrm{~W} 30$ fresh and used motor oil. Samples have the addition of effective microorganisms in liquid form in the amount of $2.5 \mathrm{ml}$ and $5 \mathrm{ml}$ and ceramic tubes in the amount of 3 pieces and 6 pieces. In addition, fresh oil and used oil without any additives were also tested to compare the viscosities obtained.

Each sample was tested for dynamic viscosity, at the temperature of $2^{\circ} \mathrm{C}$ to $63^{\circ} \mathrm{C}$. These were preliminary researches to determine whether the addition of effective microorganisms would bring the expected effect. It can be assumed that an oil, the viscosity at a given temperature is unchanged and is a parameter determining how the oil will behave at this temperature [15].

In further tests, the oil density can be determined for the same temperatures and then, using a program based on ASTM D341 interpolation, determine the most interesting kinematic viscosity of the samples at $100^{\circ} \mathrm{C}$, because the oil most often works at this temperature.

\section{Results and analysis of tests}

In order to analyse the viscosity changes for each samples, the test results are presented in the form of graphs in Fig. 5-8. These graphs show the dynamic viscosity as a function of temperature. The tests were carried out in the range from $2^{\circ} \mathrm{C}$ to $63^{\circ} \mathrm{C}$, because in this range it was possible on this research device. Fig. 5 and 6 show viscosity changes from the temperature of fresh, used and used oil samples with the addition of effective microorganisms in liquid form $(2.5 \mathrm{ml}$ and $5 \mathrm{ml}$ per $250 \mathrm{ml}$ of oil) and in the form of ceramic tubes ( 3 pieces and 6 pieces with a diameter of $9 \mathrm{~mm}$ and a height of $11 \mathrm{~mm}$ for $250 \mathrm{ml}$ of oil). The biggest differences in viscosity occur in the range from $2^{\circ} \mathrm{C}$ to $40^{\circ} \mathrm{C}$. Analysing the above results, it can be seen in Fig. 5 for a temperature of $5^{\circ} \mathrm{C}$ (high viscosity makes it difficult to start the car at low temperatures and increases resistance to the engine, thus resulting in higher fuel consumption) the dynamic viscosity for fresh oil is $473 \mathrm{~m} \cdot \mathrm{Pa} \cdot \mathrm{s}$, for used oil $553 \mathrm{~m} \cdot \mathrm{Pa} \cdot \mathrm{s}$, while after the addition of effective microorganisms (EM) in an amount of $2.5 \mathrm{ml}$ this viscosity approaches the viscosity of fresh oil and amounts even to $435 \mathrm{~m} \cdot \mathrm{Pa} \cdot \mathrm{s}$. In the case of adding $5 \mathrm{ml}$ of effective microorganisms, the viscosity increased significantly to 603 $\mathrm{m} \cdot \mathrm{Pa} \cdot \mathrm{s}$, i.e. it is higher than the viscosity for fresh oil by $130 \mathrm{~m} \cdot \mathrm{Pa} \cdot \mathrm{s}$ and $50 \mathrm{~m} \cdot \mathrm{Pa} \cdot \mathrm{s}$ higher than the viscosity value for used oil. It follows that the $2.5 \mathrm{ml}$ additive positively influenced the used oil and brought its viscosity closer to the value of fresh oil, while too many effective microorganisms, in this case $5 \mathrm{ml}$ caused a deterioration of properties and an even greater viscosity increase compared to the used oil. The additions were ceramic tubes.

Figure 6 shows that they have less impact than effective microorganisms in liquid form. Addition of 6 pieces of ceramic tubes to used oil caused the viscosity decrease to $506 \mathrm{~m} \cdot \mathrm{Pa} \cdot \mathrm{s}$ at $5^{\circ} \mathrm{C}$ and its approximation to the viscosity of fresh oil, but it is not as visible as in the case of the addition of microorganisms in liquid form. The addition of 3 ceramic tubes basically coincides with the viscosity of used oil amounting to approx. $560 \mathrm{~m} \cdot \mathrm{Pa} \cdot \mathrm{s}$ at $5^{\circ} \mathrm{C}$, therefore in further tests, the oil behaviour should be checked for a larger number of ceramic tubes.

Figure 7 and Fig. 8 show changes in viscosity from temperature for fresh and fresh oil samples with the addition of effective microorganisms in liquid form $(2.5 \mathrm{ml}$ and $5 \mathrm{ml}$ per $250 \mathrm{ml}$ of oil $)$ and in the form of ceramic tubes ( 3 pieces and 6 pieces of diameter $9 \mathrm{~mm}$ and a height of $11 \mathrm{~mm}$ for $250 \mathrm{ml}$ of oil). Both for the addition of effective microorganisms in liquid form and in the form of ceramic tubes, regardless of the amount, the viscosity increases, almost as for used oil, and amounts to approx. $570 \mathrm{~m} \cdot \mathrm{Pa} \cdot \mathrm{s}$ and $600 \mathrm{~m} \cdot \mathrm{Pa} \cdot \mathrm{s}$, for $5^{\circ} \mathrm{C}$, wherein the viscosity is $473 \mathrm{~m} \cdot \mathrm{Pa} \cdot \mathrm{s}$ for fresh oil at this temperature. 


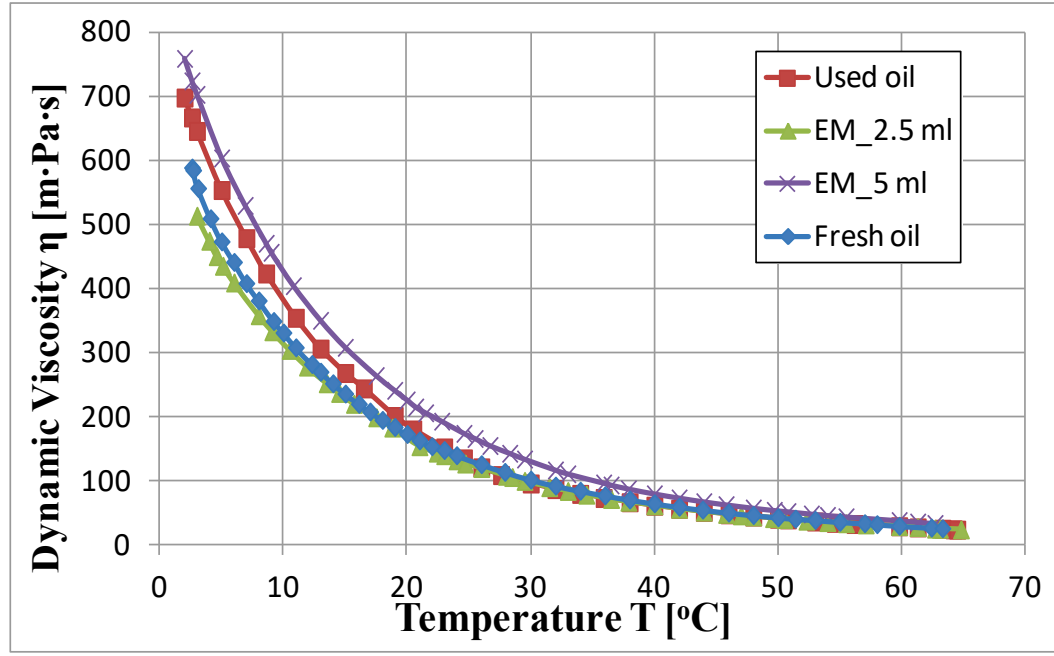

Fig. 5. Comparison of viscosity of fresh, used and used oil samples with the addition of effective microorganisms in liquid form

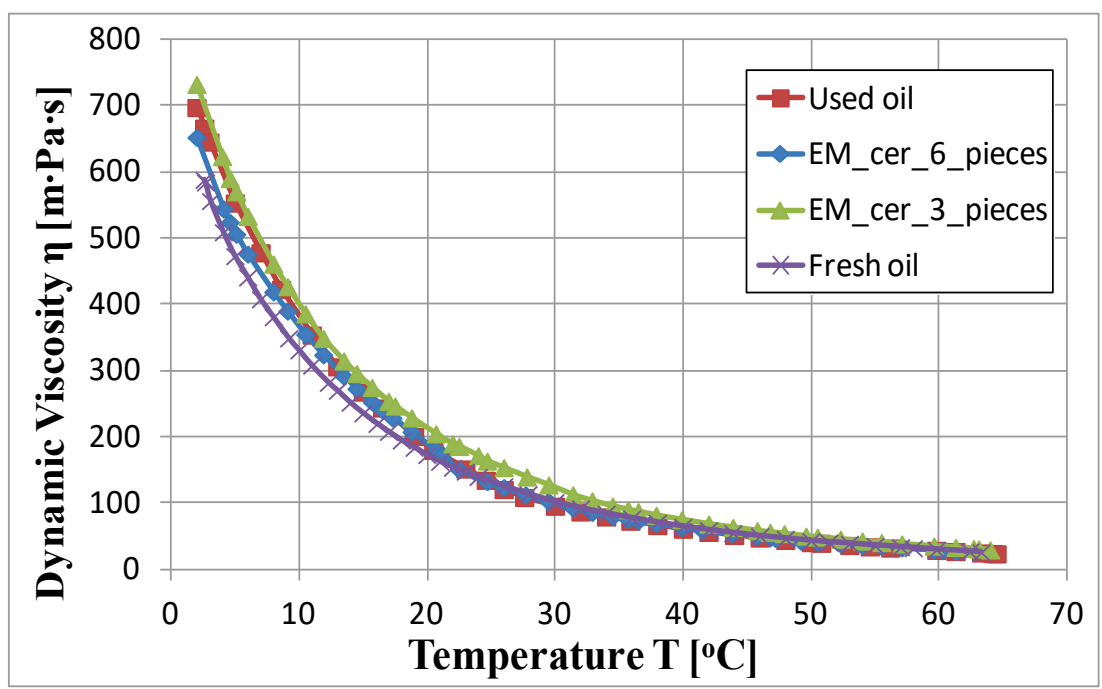

Fig. 6. Comparison of viscosity of fresh, used and used oil samples with the addition of effective microorganisms in the form of ceramic tubes

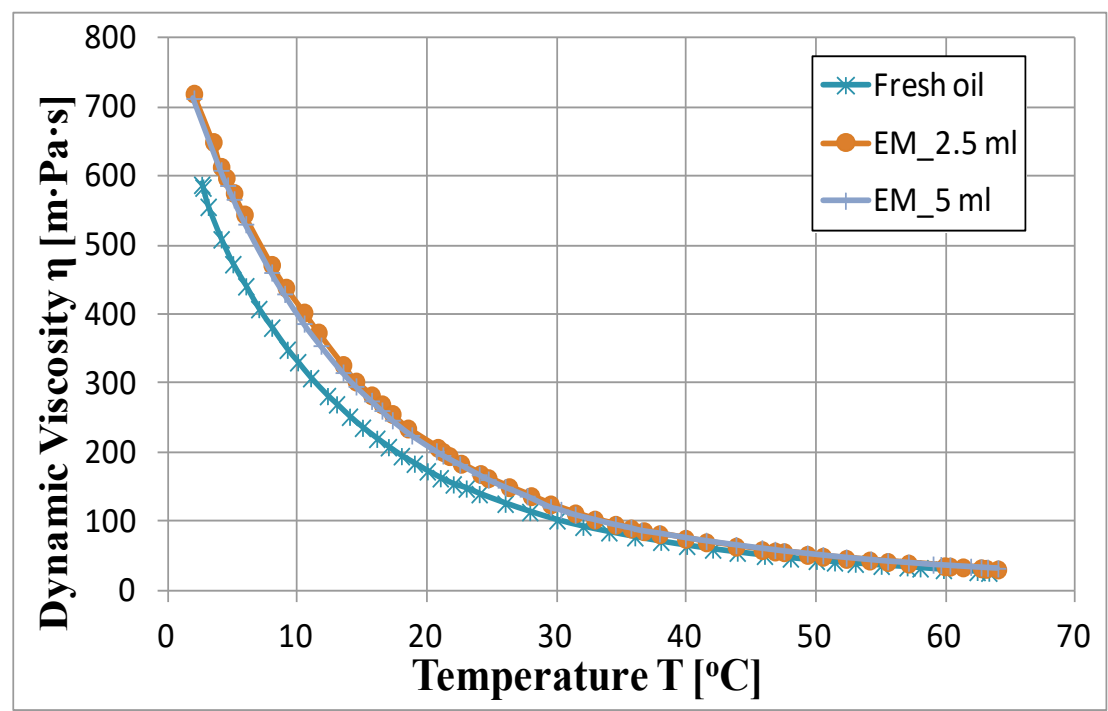

Fig. 7. Comparison of viscosity of fresh and fresh oil samples with the addition of effective microorganisms in liquid form 


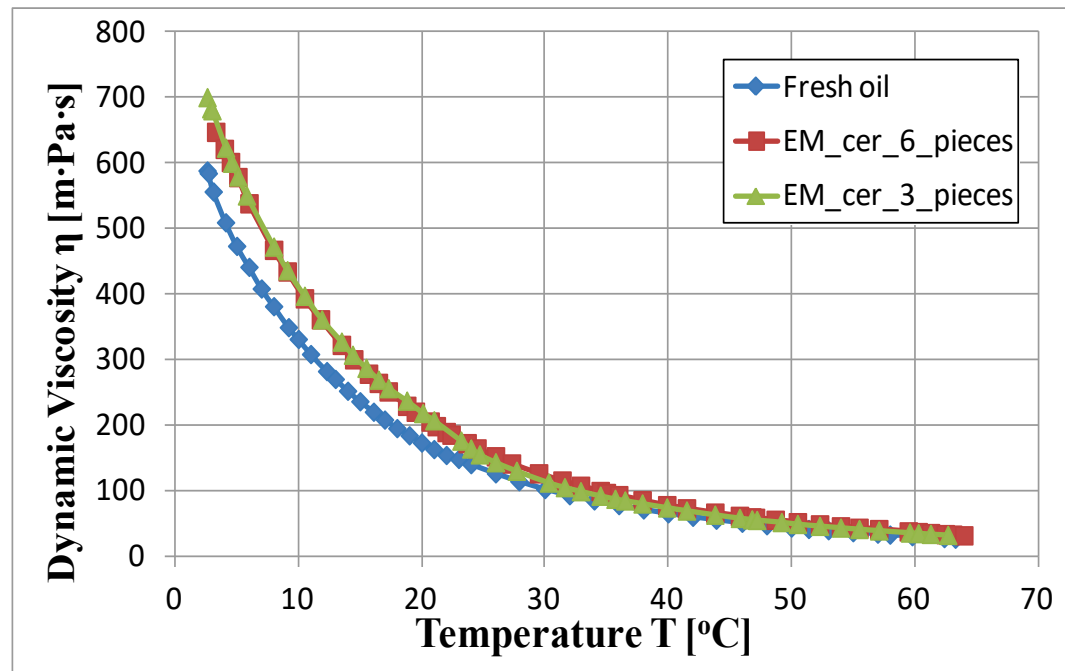

Fig. 8. Comparison of viscosity of fresh and fresh oil samples with the addition of effective microorganisms in the form of ceramic tubes

It follows that the addition of effective microorganisms to fresh oil is not desirable or even harmful, because the oil then has the properties of used oil, which may be due to the fact that in fresh oil, microorganisms do not have the right nutrient for development and they break down leading to oil degradation.

\section{Conclusions}

Currently, biocides are the most popular means of controlling microorganisms. However, their use, despite a number of benefits resulting from their use, is limited. This is due to the fear of the harmful effects of these highly concentrated substances on the natural environment. Therefore, there is a need to find new methods of combating microbial contamination, which will not destroy beneficial microorganisms and will be environmentally friendly. These conditions can be met by the technology of effective microorganisms (EM), which has enormous potential and gives the opportunity to use these properties to solve the problems of current generations of global problems.

The addition of effective microorganisms in the amount of $2.5 \mathrm{ml}$ positively affected the used oil and brought its viscosity closer to the value for fresh oil, whereas too many effective microorganisms, in this case, $5 \mathrm{ml}$ caused a deterioration of properties and an even greater increase in viscosity compared to used oil. Therefore, further studies should be conducted for smaller amounts of microorganisms.

The addition of effective microorganisms in the amount of 6 ceramic tubes to used oil resulted in lowering viscosity and bringing it closer to the viscosity of fresh oil, but it is not as visible as in the case of the addition of microorganisms in the form of liquid. The addition of 3 pieces of tubes coincides with the viscosity of used oil, which is why in further research it is necessary to increase the number of ceramic tubes. It can be noticed that the addition of effective microorganisms in a liquid form brings better results.

After the addition of effective microorganisms to fresh oil, both in liquid form and in the form of ceramic tubes, regardless of their quantity, there is a viscosity increase similar to that of used oil. This means that the addition of effective microorganisms to fresh oil is not desirable or even harmful, because the oil then has the properties of used oil.

As part of further research, it is planned to check, inter alia, the presence of water and impurities in diesel and lubricating oils, flash point, elemental composition of the tested samples, and in the longer term the impact on the composition of exhaust gases and the aging process of lubricating oils. 


\section{Reference}

[1] Duda, A., Problemy skażenia mikrobiologicznego $w$ dystrybucji $i$ magazynowania paliw naftowych, Konferencja Naukowo-Techniczna „Ekologia w przemyśle rafineryjnym“, Kielce 2001.

[2] Fitch, J., Trouble-Shooting Viscosity Excursions, Practicing Oil Analysis Magazine, Iss. 5, machinerylubrication.com/Magazine/Issue/PracticingOilAnalysis/5/2001, 2001.

[3] Gaylarde, C. C., Bento, F., Kelley, J., Microbial contamination of stored hydrocarbon fuels and its control, Revista de Microbiologia, Vol. 30, No. 1, pp. 1-10, 1999.

[4] George, S., Balla, S., Gautam, V., Gautam, M., Effect of diesel soot on lubricant oil viscosity, Tribology Int., Vol. 40, Iss. 5, pp. 809-818, 2007.

[5] Idzior, M., Wichtowska, K., Badanie wpływu przebiegu pojazdów na zmiany właściwości olejów silnikowych, Autobusy: technika, eksploatacja, systemy transportowe, R. 17, No. 6, pp. 900-904, 2016.

[6] Janda, K., Mikrobiologiczne skażenie paliw, Postępy mikrobiologii, Vol. 44, No. 2, pp. 157169, 2005.

[7] Kolasa-Więcek, A., Czy efektywne mikroorganizmy zrewolucjonizuja świat? Postępy Techniki Przetwórstwa Spożywczego, No. 1, pp. 66-69, 2010.

[8] Malinowska, M., The evaluation of viscosity properties of engine oil - Marinol RG 1240 after working in various types of engines, Journal of KONES Powertrain and Transport, Vol. 25, No. 1, pp. 275-281, 2018.

[9] Markova, L. V., Makarenko, V. M., Semenyuk, M. S., Zozulya, A. P., On-line monitoring of the viscosity of lubricating oils, Journal of Friction and Wear, Vol. 31, No. 6, pp. 433-442, 2010.

[10] Schicht, M. L., Zrozumieć efektywne mikroorganizmy (EM), EMECHO, No. 8, 2008.

[11] Tripathi, A., Vinu, R., Characterization of Thermal Stability of Synthetic and Semi- synthetic Engine Oils, Indian Institute of Technology Madras, Chennai 2015.

[12] Wills, J., Facts about Engine Oil, Agricultural Extension Service, The University of Tennessee, 2015.

[13] www.labindex.pl/lepkosciomierze/lepkosciomierze_wibracyjne_sv.html.

[14] www.saion-em.com.my/aboutem.xhtml.

[15] www.warsztat.castrol.pl/blog-post/co-jest-lepkosc-oleju-silnikowego/. Manuscript received 15 July 2019; approved for printing 23 September 2019 